DOI: $10.17516 / 1997-1370-0541$

УДК 347.919 .3

\title{
Development of Simplified Procedures in Civilistic Process in the Context of Legislative Reforms
}

\author{
Tatyana V. Sakhnova* \\ Siberian Federal University \\ Krasnoyarsk, Russian Federation
}

Received 30.10.2019, received in revised form 30.12.2019, accepted 10.01.2020

\begin{abstract}
The article is devoted to the problems connected with the unification of a number of judicial procedural and non-procedural codes of practice in modern civilistic process of Russia. These problems are reviewed in terms of ontology, taking into account new legislative statutes of 2018-2019. Unification and differentiation of judicial procedures is a twin-track trend of the civilistic process, stemming from globalization of the procedural in the $21^{\text {st }}$ century. At the same time, the general regularity is achieved in different ways depending on the type of process and its national realisation. The judicial procedures, which have a structural specificity in relation to the general, "extended" judicial procedure within the civilistic procedural form, cannot be reduced to simplified procedures and simplification of the process only, but rather these procedures testify to the complication of the civilistic process. This article substantiates the thesis that an increase in the coefficient of applied efficiency of the civilistic process can only be implemented through reaching a balance of private law and public law in judicial procedures. The conclusions regarding the essence of court procedures and the methodology of their application in the procedural law are meaningful as regards lawmaking and law enforcement activities.
\end{abstract}

Keywords: civilistic process, court procedures, simplified proceedings, writ proceedings, proceedings in absentia, minor cases procedure, justice.

Research area: civil process, arbitration process.

Citation: Sakhnova, T.V. (2020). Development of simplified procedures in civilistic process in the context of legislative reforms. J. Sib. Fed. Univ. Humanit. Soc. Sci., 13(1), 103-115. DOI: 10.17516/1997-13700541

(C) Siberian Federal University. All rights reserved

* Corresponding author E-mail address: civil.law.process@gmail.com 


\section{Introduction}

The $21^{\text {st }}$ century was marked by cardinal reforming of the civilistic (sometimes in foreign sources called civil) process. This reforming was caused by the general processes of law globalization, by the search for effective ways of harmonization of material and procedural law, by the increasing role of civilistic procedural law as a system-forming factor in the national system of law and as the main procedural mechanism of interaction of national jurisdictions. Under these conditions, the internal harmonization of the civilistic process becomes an indispensable prerequisite for development, without which its historical mission cannot be possibly realized.

The working tools for solving this problem are procedures. Procedurality seems to be an obvious and immanent property of the civilistic process. At the same time, it does not necessarily correlate with its legislative concept: the process can follow either the procedural (Roman law tradition) or institutional (German-Austrian tradition) model (Sakhnova, 2009: 25-40). Historically, the Russian process, as a continental process in its essence, did not take home any of these approaches, but instead, it sought to avail of foreign experience in creating its own procedural mechanism of judicial protection (the experience of the Civil Procedure Statute presents a highly relevant methodological example here). However, by its type, Russian civilistic process has had a penchant for the institutional process, which developed under the influence of the German historical school. The situation began to change with the adoption of the RF Civil Procedure Code (hereinafter referred to as CPC) and the RF Arbitration Procedure Code (hereinafter referred to as APC) in 2002, which, in our assessment, gave a powerful impetus to the procedural development of the civilistic process. Yet, it was more a consequence of the internal evolution of the process triggered by the needs of self-development than a doctrinally conscious action.

Nevertheless, the new direction was set and further reform of the domestic civilistic process and procedural law in the $21^{\text {st }}$ century took place under the aegis of the development of procedures: judicial and non-judicial, judicial procedural and judicial non-procedural modifications; procedures of justice and related to the provision of indisputable rights. The Roman justitia in both senses of the word is neither normative nor declarative anymore; it seeks to find its procedural embodiment in various hypostases as an applied methodology of justicelfairness.

In this context, one of the most controversial tasks concerning the methods of solution has become the task of increasing the efficiency of civilistic court proceedings via the introduction of procedures in the procedural law that differ from the usual, "extended" procedure of consideration and resolution of the case in full compliance with all rules of civilistic procedural form.

In the newest period, the development of the Russian procedural legislation saw the introduction of the default judgment and writ proceedings, introduced in the CPC of the RSFSR in 1995, followed by the "simplified procedure" of the APC of the RF released in 2002.

The civilistic process reform, which occurred later in the $21^{\text {st }}$ century, revived the idea of accelerating/simplifying/optimizing the process and those concerned started to discuss this idea. In modern Russian doctrine, it is common practice to unite all procedures that differ from the general civilistic procedural form, namely writ proceedings, trial in absentia, and simplified production. They fall under a generalized and formalized denomination of "acceleration" and "simplification" (Kudriavtseva, 2010: 412, 425; Malyshkin, 2017; Reshetnikova, 2019: 132-127; Iarkov, 2012: 362, 366-368). The traditional criterion for selection in this case is the subject one.

In our opinion, on the contrary, the development of different legal procedures is not a sign of simplification, but rather of the greater complexity of the legal space, which is becoming more and more diverse and at the same time "stricter", requiring systemic consolidation for its effective functioning. The development of judicial procedures is an indicator of the complication of the civilistic process, a clear manifestation of the general regularity, i.e. unification and differentiation of the civilistic procedural form (Sakhnova, 2004: 25-35; 2014: 7, 
$73,92-94,99)$. It is in this very context that the mentioned procedures (simplified proceedings, writ proceedings, trial in absentia) should be studied. Minor cases procedure, as it is understood abroad, could also be added to this list. ${ }^{1}$ Despite the fact that the Russian legislators do not use such terminology, the amenability to suit in the magistrate court and the peculiarities of the adoption of court decision on them grant an opportunity to discuss such a procedural phenomenon.

\section{Simplified proceedings}

Simplified proceedings as an independent judicial procedure of the newest times first appeared in the APC of the RF in 2002 (Chapter 29 "Consideration of Cases in Simplified Proceedings"), which has undergone more than two dozen legislative changes so far. In the Civil Procedure Code of the Russian Federation, simplified legal proceedings were introduced in $2016^{2}$ in the tidal wave of the unification of civilistic procedures officially set forth by the adoption of the Concept of the Unified Civil Procedure Code of the Russian Federation on December 8, 2014. ${ }^{3}$ Accordingly, it was natural that the Code of Administrative Judicial Procedure of the Russian Federation (hereinafter referred to as CAJP), adopted in 2015 , included simplified proceedings (Section V "Simplified (Written) Proceedings on Administrative Cases"). The last innovation of simplified proceedings in the RF Civil Procedure Code, the RF Arbitration Procedure Code and the RF Code of Administrative Judicial Procedure was prescribed by the RF Federal Law No. 451-FZ of November 28, $2018 .{ }^{4}$

\footnotetext{
1 Regulation (EU Council) No. 861/2007 of 11 July 2007 on the introduction of European proceedings for de minimus requirements. In JOCE, 2007.

2 On Introducing Amendments to the Civil Procedure Code of the Russian Federation and the Arbitration Procedure Code of the Russian Federation: Federal Law of the Russian Federation of March 2, 2016, No. 45-FZ. In Code of Laws of the RF, $2016,10,1319$

3 Approved by the Committee for Civil, Criminal, Arbitration and Procedure Law of the State Duma of the Federal Assembly of the Russian Federation of December 8, 2014, No. 124(1).

4 On Introducing Amendments to Certain Legislative Acts of the Russian Federation: Federal Law of November 28, 2018, No. 45-FZ. In Code of Laws of the RF, 2018, 49 (1), 7523.
}

According to the current legislation, simplified proceeding is an independent judicial procedure, inscribed in the general civilistic procedural form, but having procedural peculiarities (cf: Part 1 of Article 226 of the CPC RF, part 1 of Article 232.1 of the CPC RF). I believe that the initial legislative postulate, nemly "cases in the rule of simplified proceedings shall be considered in agreement with the general rules of claim proceedings...", is fundamental for qualification of this procedure. Section V of the CAJP of the Russian Federation does not contain a reference to the general rules of consideration of administrative cases and the very name of the procedure equals simplified proceedings with written proceedings. So, this approach could imply some peculiarity which brings this procedure beyond the general procedural form. Nonetheless, this is not true, which is proved by the consequent rules that demonstrate the impact of stakeholders' willingness to use simplified or extended court proceedings. Undoubtedly, it is impossible not to take into account de lege ferenda unity of the concept of a civilistic procedural form and procedural criteria of its differentiation.

In the Russian civilistic process, the simplified proceedings are simplified court procedures divided into two types: 1) mandatory - by operation of law (Para. 1-5 of Part 1, Para. 1-2 of Part 2 of Article 227 of the RF APC; Para. 1-3 of Part 1 of Article 232.2 of the RF CPC); 2) optional - by willingness of the parties (Part 3 of Article 227 of the RF APC, Part 2 of Article 232.2 of the RF CPC). As for the RF CAJP, the legislative prescriptions are different, this Code does not provide for mandatory character of simplified proceedings, but links their possibility with the expression of will of the parties: (a) all persons involved in the case do not mind their case to be considered in their absence (if their participation in the case is not mandatory by law); (b) the administrative plaintiff agrees that the case will be considered by way of the simplified proceedings, if the administrative defendant does not object to it (Para. 1-2 of Part 1 of Article 291 of CAJP of the Russian Federation). There is an important remark here: the absence of a party/parties does not qualify a court procedure as simplified proceedings 
under the Civil Procedure Code of the Russian Federation and the Arbitration Procedure Code of the Russian Federation. As a matter of fact, the CAJP of the Russian Federation has united the criteria of two different procedures (trial in absentia and simplified proceedings) in the simplified (written) procedure. The subject criterion (amount claimed), important for the qualification of a mandatory simplified procedure as such under the RF CPC and the RF APC, under the CAJP retains its significance only as a limiting factor, indicating the subject limits of possible simplified proceedings, when "the total amount of debt on mandatory payments and sanctions specified in the administrative statement of claim does not exceed twenty thousand roubles" (Para. 3, Part 1, Article 291 of the RF CAJP). All three codes also use the criterion of "category of cases" as a decisive factor of admissibility/inadmissibility to use simplified procedures (see: Part 3 of Article 232.2 of the Civil Procedure Code of the Russian Federation, Part 4, Article 227 of the Arbitration Procedure Code of the Russian Federation, Part 2, Article 291 of the Code of Administrative Judicial Procedure of the Russian Federation).

Mandatory simplified proceedings are legally oriented to the subject criterion (amount of a claim, indisputability of obligations). Optional simplified proceedings have the main procedural criterion which is the expression of will of the parties.

Simplified proceedings are judicial and adversarial process that meets the basic postulates of the civilistic procedural form (with some peculiarities of their manifestation), in which the powers of the court ex officio do not take the main place, though they are still important for procedure characterization.

Simplified proceedings are a two-sided procedure: the optional one requires taking into account the will of both parties; the return to the general procedure of consideration of the case is connected with the involvement of a third party putting independent claims or a counterclaim (cf. Parts 2 and 4 of Art. 232.2 of the RF CPC, Parts 3 and 5 of Art. 227 of the RF APC, Parts 2-5 of Art. 292 of the RF CAJP).

Simplified proceedings are the adversarial process, which is realized in various aspects related both to the evidential activity itself and to securing the adversarial rights of the parties. It should be noted that in line with the general trend of unification of the civilistic process these rights were bought to a common standard of the Federal Law of the Russian Federation No. 451-FZ of November 28, 2018.

(1). The legislators have envisaged that the return to the general procedure of consideration of the case may be caused by the need, inter alia of the request of one of the parties to identify and / or examine additional evidence, including expert assessment and testimony; "the action brought is associated with other requirements, including to other persons, or the judicial act adopted in this case, when the rights and legitimate interests of other persons may have been violated" (cf. Para. 1-2 of Part 4, Art. 232.2 of the RF CPC, Para. 2-3 of Part 5, Art. 227 of the RF APC, Para. 2-3 of Part 7, Art. 292 of the RF CAJP).

(2). The power of the court ex officio is to set the deadline for the parties to submit evidence and objections to each other (within 15 days of the date of the relevant determination), as well as additional documents containing "explanations on the essence of the claims and objections in support of their position" (within 30 days starting from the date of the relevant rendering of the decision), which should not contain a reference to evidence that was not submitted within the fifteen-day time limit (Parts 2, 3 of Art. 232.3 of the RF CPC, Parts 2, 3 of Art. 228 of the RF APC, Part 5 of Art. 292 of the RF CAJP). These conditions are aimed at ensuring real adversarial proceedings in the absence of the parties at a court session in simplified proceedings (Part 5 of Art. 232.3 of the RF CPC, Part 5 of Art. 228 of the RF APC).

(3). In any case, "the court shall investigate explanations, objections and/or arguments of persons involved in the case and presented by the parties, and shall take a decision on the basis of the evidence presented within the specified time limits" (Sub-Paragraph 2 of Part 5, Art. 232.3 of the RF CPC, Sub-Paragraph 3 of Part 5, Art. 228 of the RF APC, Part 1, Art. 292 of the RF CAJP). This approach corresponds to the Roman procedural tradition (as opposed to the German-Austrian institu- 
tional one, which is focused on the fact of the existence/absence of the defendant's objection, but instead of the validity of the circumstances of the claim presented by the plaintiff).

(4). At the same time, the Russian legislators follow an institutional tradition (but in its mitigated version) to take actions when the parties fail to honour the date set by the court for the submission of evidence and explanations. "If evidence and other documents have been submitted to the court prior to the adoption of the decision on the case, but after the deadline set by the court expired, the court shall accept such evidence and other documents provided that the deadline for their submission has been missed for sound reasons" (Part 4 of Article 232.3 of the RF CPC, Part 4 of Article 228 of the RF APC). Otherwise, the court shall not consider evidence and/or documents and shall return them to the persons concerned who have submitted them. The RF CAJP does not contain such clarifications, which we believe to be a legislative omission. Let us compare this with institutional proceedings, where the failure to meet the deadline for submission of evidence regardless of the type of judicial procedure is an unconditional reason for the non-admittance of evidence in the process. For example, according to Para. 2 of Art. 179 of the Austrian Civil Procedure Code, the explanations of the parties are not accepted by the court, too, if their acceptance would create an obstacle to the further movement of the case, that is the principle that "everything must be presented in due time", which is characteristic of the concept of social process.

Since there are no oral hearings in the simplified proceedings, hence the rules on record keeping and on postponement of proceedings are not applied, and preliminary court session is not held (Part 6 of Article 232.3 of the Civil Procedure Code of the Russian Federation, Para. 2 of Part 5, Part 6 of Article 228 of the Arbitration Procedure Code of the Russian Federation). A decision on a case considered by simplified proceedings is taken by the court by means of pronouncing an operative part of the decision (Part 1 of Article 232.4 of the RF CPC, Part 1 of Article 229 of the RF APC), however, the court shall draw up a reasoned decision following the application of persons involved in the case, or their representatives (submitted within 5 days from the date of signing the operative part of the court decision) or in case of filing an appeal or representation for the case (Parts 2, 3 of Article 232.4 of the RF CPC, Part 2 of Article 229 of the RF APC). In the appellate court, the court decision made in simplified proceedings is appealed in shortened terms - within 15 days from the date of the decision in the final form (see Part 8 of Article 232.4 of the RF CPC, Parts 3, 4 of Article 229 of the RF APC). And again, let us cite for clearness the general indication of the RF CAJP in Art. 293 that "the decision on the administrative case, considered in the order of the simplified (written) proceedings, is taken in the light of the rules established by Chapter 15 of this Code and corresponding to the essence of the simplified (written) proceedings". Still nobody knows what these rules, corresponding to the substance of the simplified (written) proceedings and the enforcer, are, therefore what is left here to do is to rely on the analogy of the law only (Part 4 of Art. 2 of the RF CAJP). Meanwhile, it is necessary to pay attention to the following: since in administrative proceedings, including the sphere of judicial cognition and proving, the public-legal principles dominate in the process (the subject of proving is worded according to the case and it is set by the court; the court has wide powers ex officio in filling the case with evidential material (cf.: Part 3 of Art. 62, Parts 1-2 of Art. 63 of the RF CAJP), then, perhaps, it is not accidental that there are no rules of simplified proceedings in the RF CAJP regarding that the court decision is made by the method of signing of the operative part only. Does the court make a reasoned decision in any case? A positive answer to this question seems to be the right one. However, the above wording of Art. 293 of the RF CAJP ("... and corresponding to the essence of the simplified (written) proceedings...") is confusing and consequentially leads to another way of thinking This is a conceptual contradiction, which requires legal resolution.

On the contrary, the situation, when the simplified proceedings were initiated under the rules that existed before the entry into force of 
the Federal Law of the Russian Federation of November 28, 2018 No. 451-FZ ${ }^{5}$, and when the judicial review and procedural actions are carried out after the aforesaid Federal Law came into force, turns out to be quite transparent and based on the well-known rule of the procedural law in space and time. Nevertheless, the Plenum of the Supreme Court of the Russian Federation decided to pay heed to this in its Resolution No. 26 of July 9, 2019, which may not be exaggerated in practice.

Thus, simplified proceedings under the current Russian law are characterized by the absence of uniform qualification and classification criteria. Substantive (material) and imperative approaches prevail; they define and determine, in fact, the procedural criterion associated with the will of the parties. In our opinion, the future development of the civilistic process in general is connected with the actualization of the private law basis in the methods of the process, which is first of all manifested in two points: (1) the main criterion of differentiation and unification of the process lies in procedures, which are correlated with each other also by (2) mainly procedural criteria. This will ensure the unity of the methodology of the civilistic process as a means of its internal harmonization. In this, one may discern the way to achieve the applied goals of increasing the efficiency of the judicial protection, understood not in the sense of extensive development (by the method of "arithmetic" multiplication of the number of judicial procedures), but rather in the new realities of constitutionalization and materialization of the process, when the civilistic process acquires once lost trait of justitia. Therefore, de lege ferenda the procedural criterion, i.e. the will of the parties, is supposed to be the main one when choosing a judicial procedure, including simplified proceedings. The subject criterion can be that simplified

\footnotetext{
5 On some issues of application of the Civil Procedure Code of the Russian Federation, the Arbitration Procedure Code of the Russian Federation, the Code of Administrative Judicial Procedure of the Russian Federation in connection with the enactment of the Federal Law of November 28, 2018, No. 451FZ "On Introducing Amendments to Certain Legislative Acts of the Russian Federation". Resolution of the Plenum of the Supreme Court of the Russian Federation No. 26 dated July 9, 2019, published in Rossiyskaya Gazeta, 2019, 17 July.
}

proceedings are legally fixed as compulsory (as a type of simplified procedure), providing that consent to this form of procedure has been given. Be that as it may, the persons concerned must be guaranteed the possibility of judicial protection in a detailed procedure, under all the rules of the civilistic procedural form. Such approach will also contribute to the applied mechanism of creation of a new ideology procedural cooperation between the court and the parties (the ideology of their procedural opposition has long outdated itself), which comes across to be the only fruitful in the conditions when the unified Code of Civil Procedure of the Russian Federation is being compiled

\section{Writ proceedings}

Writ proceedings as judicial but not procedural in nature first appeared in the CPC of the RSFSR in 1995 (Chapter 11.1 "Court Order"), ${ }^{6}$ which was later transformed into "Subdivision I. Writ Proceedings", making one Chapter 11 "Court Order", in the CPC of the Russian Federation in 2002. This structure is still relevant today, although the institution itself was afterwards subjected to numerous legislative revisions. In the APC of the Russian Federation, the court order appeared in 2016: the Federal Law of the Russian Federation of 2 March 2016, No. 47-FZ introduced Chapter 29.1 "Writ Proceedings", which is contained in Section IV "Specifics of Proceedings in the Arbitration Court for Certain Categories of Cases"7. In this Section, which has been created without any certain concept, this description of writ proceedings is presented strangely enough. In the same year (2016), the writ proceedings penetrated into the RF CAJP (Chapter 11.1 "Proceedings on Administrative Cases on Delivering a Court Order"). ${ }^{8}$

\footnotetext{
6 On Introducing Amendments and Additions to the RSFSR Civil Procedure Code: Federal Law of the Russian Federation of November 30, 1995, No. 189-FZ. Code of Laws of the RF, 1995, 49, 4696.

7 On Introducing Amendments to the Arbitration Procedure Code of the Russian Federation: Federal Law of the Russian Federation of March 2, 2016, No. 47-FZ. Code of Laws of the $R F, 2016,10,1321$.

8 See: On Introducing Amendments to the Code of Administrative Procedure of the Russian Federation and Certain Legislative Acts of the Russian Federation: Federal Law of the Rus-
} 
As has been noted, modern doctrine has often viewed writ proceedings in the context of accelerating the process, which is an ontological error. This is followed by Paragraph 11.1 of the Concept of the Unified Civil Procedure Code of the Russian Federation, which defines writ proceedings "as a type of civil proceedings" that "is characterized by a simplified procedural form". 9 The Plenum of the RF Supreme Court also followed the same path, characterizing writ proceedings as "one of the forms of simplified proceedings". ${ }^{10}$ Suffice it to look at the legislative rules to see that the opposite is true: writ proceedings are not included in the procedural form at all, and de lege ferenda do not need this. Notwithstanding that, the Concept does not suggest any changes to the concept of a court order in the Unified Civil Procedure Code of the Russian Federation, quite the contrary, there is a conclusion made that "it is necessary to fully reproduce the chapter of the existing Civil Procedure Code devoted to the court order in the draft of the new Code". ${ }^{11}$ Critical objections to the subject matter of this approach were voiced during the discussion of the draft Concept (Sakhnova, 2015: 14-15) and they remain pertinent to this day.

A court order is a non-procedural judicial process that lies outside the civilistic procedural form and is aimed at ensuring undeniable rights. The criterion of indisputability in its substantive and procedural sense is considered to be among the most important ones by the Plenum of the RF Supreme Court. ${ }^{12}$ There is no process or justice here; a court order is not an analogue of a court decision (Sakhnova, 2015:

sian Federation of April 5, 2016, No. 103-FZ. Code of Laws of the $R F, 2016,15,2065$

9 Concept of the Unified Civil Procedure Code of the Russian Federation. Moscow, Statute, 2015, 67.

${ }^{10}$ Sub-Paragraph 2 of Para. 22 of the Resolution of the Plenum of the Supreme Court of the Russian Federation of December 27, 2016, No. 62 "On Some Issues of Application by the Courts of the Provisions of the Civil Procedure Code of the Russian Federation and the Arbitration Procedure Code of the Russian Federation on the writ proceedings". In Bulletin of the Supreme Court of the RF, 2017, 2.

${ }^{11}$ Concept of the Unified Civil Procedure Code of the Russian Federation. Moscow, Statute, 2015, 69.

${ }_{12}$ Items 3,4 and following of the Resolution of the Plenum of the Supreme Court of the Russian Federation of December 27, 2016, No. 62
14-15), but it has the force of an executive document, so it has an executive judicial significance (though not legal!). ${ }^{13}$

Writ proceedings under Russian law cannot be compared with Mahnverfahren (Paragraphs 688, 700 of the German Civil Procedure Code) because of their different concept. Mahnverfahren is a special procedure characterized as a "pre-process" in the proceedings, which is inscribed in a civilistic procedural form. That is why, when the defendant raises a legal objection to the plaintiff's claim, he or she gets into the plaintiff's procedural position and has to justify it, so the procedure becomes of the claim nature. In this case there are no fundamental changes in the general algorithm of the process and the Roman principle of proof ei incubit probatio qui dicit in this situation remains in full force and effect (Sakhnova, 2011: 45). The Russian concept is fundamentally different: the court order is procedurally unrelated to the claim proceedings; there is no process here; the debtor's objection to the execution of the court order may also be unreasoned, though under a certain condition: if filed within 10 days from the date of receipt by the debtor of the order (see Parts 3, 5 of Art. 128 of the Civil Procedure Code of the Russian Federation, Art. 229.5 of the Arbitration Procedure Code of the Russian Federation). This legislative provision is a guarantee of the right to judicial protection by means of a lawsuit, because no one can be limited in the right to judicial protection, which meets all the requirements of the civilistic procedural form, and the fact of objection itself is the evidence of a possible dispute about what is inadmissible in the writ proceedings. The consequence of such an objection may be the cancellation of the court decision and the possibility of the plaintiffs to defend their rights in

\footnotetext{
13 Introduction in Art. 229.5 of the Arbitration Procedure Code of the Russian Federation and Art. 123.1 of the Code of Administrative Judicial Procedure of the Russian Federation of the wording on the legality of a court order ("The court order comes into force”, “... an enforceable court order...”) appears to be an obvious misunderstanding in legislation in the light of the said above and taking into account legal qualification of a court order as an enforcement document.

Such approach, I think, is affected by the unsolved general problem of differentiation of court judgments (acts) depending on the court procedures, by which they (resolutions, acts) are terminated, which I have repeatedly mentioned.
} 
the lawsuit (compare Art. 129 of the RF CPC, Art. 229.5 of the RF APC, Part 1 of Art. 123.7 of the RF CAJP).

One may recall that the RF APC legally allows the debtor to raise an objection to the execution of a court order even after the expiration of the term established by law, but under one condition: when he or she has justified the impossibility to submit an objection within the established term for reasons beyond the debtor's control (Part 5 of Article 229.5 of the RF APC). The Civil Procedure Code of the Russian Federation does not contain such a rule, however, by virtue of the analogy of the law (Part 4 of Article 1 of the Civil Procedure Code of the Russian Federation) objections of the debtor concerning the execution of the court order may also be submitted to the magistrate court after the established term. ${ }^{14}$

Russian procedural legislation treats writ proceeding to a certain extent as an alternative to the procedure of claim proceedings. It is comparable: the judge returns the statement of claim if "the stated claims are subject to consideration in the order of the writ proceeding" (Para. 1.1 of Part 1 of Article 135 of the Civil Procedure Code of the Russian Federation, Para. 2.1 of Part 1 of Art. 129 of the Arbitration Procedure Code of the Russian Federation). This rule takes into account only static, subject criterion, reflected in Art. 122 of the RF CPC, Art. 229.2 of the RF APC. At the same time, for qualification of the procedure as writ proceedings, the procedural criterion is no less important. And it is absence of a dispute about the right. The otherwise makes the order procedure impossible and entails refusal to accept an application for delivering a court order (cf.: Para. 3 Part 3 of Art. 125 of the RF CPC, Para. 3 Part 3 of Art. 229.4 of the RF APC). Thus, the question arises: shall a judge, when deciding whether to accept an application for a court order, identify/verify if there is a dispute on the right? I am of the view that the very statement of the question is unlawful, as it destroys the concept established since the Statute of Civil Procedure, according to which (unlike the German view) "when a person concerned

\footnotetext{
${ }^{14}$ Item 33 of the Resolution of Plenum of the Supreme Court of the Russian Federation of December 27, 2016, No. 62.
}

expresses an interest in the judicial protection, this situation, coupled with his/her legal capacity and will" is a sufficient condition for the initiation of proceedings (Nefed'ev, 2005: 64-69, 75-76). In other words, in order to initiate judicial proceedings, the assumption of the interested person him- /herself (but not of the court or the norm of objective law!) that there is a dispute about the law is of qualifying importance. On the contrary, there will be no contradiction, when determining the possibility of judicial but non-procedural process (which is writ proceedings), the judge on the basis of the documents attached to the application will make sure that there is no dispute about the law. Here, the judge's doubt about the indisputability of the requirement, concerning which the court order is sought, has a qualifying meaning and acts as a public-law guarantee of the right to judicial protection, as a right to trial. Introduced in 2016, the rules of Paragraph 1.1 of Part 1 of Art. 135 of the RF CPC, Paragraph 2.1 of Part 1 Art. 129 of the RF APC are in conflict with the concept of a claim acknowledged by the legislation, prerequisites and conditions of the right to appeal to the court. So, these rules demonstrate some logic derivative from the jurisdiction, which has already lost its legal existence, and thereby, I presume, they should be abandoned as being not thought out and even harmful to the future development of judicial procedures.

I examine writ proceedings in the context of judicial non-procedural practices, which should not, however, be walled off from the process, as they are quite capable of interacting with it in a certain procedural way without becoming part of it. The fact that this is an attainable goal and, at the same time, the best way to acquire a new quality for justice itself is a clear illustration of the procedural development of the Roman process, whereas the example of France that was recurrently cited is particularly inspiring.

\section{Proceedings in absentia}

In the analyzed context it is impossible to ignore the proceedings in absentia, which have appeared for the first time (after the Statute of Civil Procedure) in the Civil Procedure 
Code of RSFSR in 1995 in the form of Chapter 16.1 "The decision in absentia"15; the current Civil Procedure Code regulates this procedure in Chapter 22 "The proceedings in absentia" (in the latest version of the Federal Law of the Russian Federation from November 28, 2018, No. 451-FZ). The modern doctrine often classifies absentee proceedings as a type of accelerated production (Reshetnikova, 2013: 93-98) or a simplified procedure in a broad sense (Terekhova, 2018: 13-20). At the same time, this view is not the only one. As a reminder, the outstanding pre-revolutionary processualist E.V. Vas'kovskii classified the absentee proceedings as complications of the process (Vas'kovskii, 2003: 363-367); modern researchers who look into the essence of the absentee proceedings point to their subordination to the regularities of the ordinary procedure of court proceedings, which leaves no room for qualification of the absentee proceedings as a simplified procedure (Reshetniak, Chernykh, 1997, Sivak, 2011). In order to solve this issue, I reckon it is important to remember the possible legislative structures of the absentee proceedings known to modern law enforcement agencies; they differ significantly. For example, in the continental process, the trial in absentia is also a court proceeding inscribed in a civilistic procedural form, but with peculiar consequences due to different initial concepts of process construction: in France (the theory of liberal process), a claim is satisfied if the plaintiff proves its grounds, in Germany (the theory of social process), facts not contested by a defendant who does not show up for trial are recognized as existing. In common law countries, a default judgement is a consequence of non-compliance with procedural formalities (not a legal process!), not related to the matter of the dispute; it is rather a clerical document (Kudriavtseva, 2008: 121, 127). In Russia, the legislators, when settling a default judgement (and subsequently, trial in absentia), have adopted a French tradition (Nefed'ev,

\footnotetext{
${ }^{15}$ Introduced by Federal Law No. 189-FZ of November 30, 1995 "On Amendments and Additions to the RSFSR Code of Civil Procedure". Codes of Law of the Russian Federation, 1995, 49, 4696 (expired on July 1, 2003, after enactment of the Civil Procedure Code of the Russian Federation in 2002).
}

2005, Textbook of Russian Civil Procedure: 333-334): a default judgement is made according to the general rules of ordinary procedure on the basis of the evidence examined by the court, presented by the persons participating in the case (cf.: Art. 234, 235 of the Civil Procedure Code of the Russian Federation).

In the light of the above, we believe that there is no reason to consider absentee proceedings under the RF Civil Procedure Code in the context of simplified procedures or some mythical acceleration of the process. This was not the objective and goal. The introduction of them was about creating procedural guarantees of the right to judicial protection for a bona fide plaintiff wishing to have a judicial protection and a trial. No-show of the duly informed defendant, who has not informed the court about the reasons of absence and has not asked for consideration of case in his/her absence (Part 1 of Article 233 of the Civil Procedure Code of the Russian Federation), should not be the obstacle for the due protection of the plaintiff's interests. Simultaneously the expression of will of the claimant concerning trial in absentia has qualifying value: in the absence of his/her consent to the given procedure the court adjourns court session and notifies the defendant repeatedly (Part 2 of Article 233 of the Civil Procedure Code of the Russian Federation). The peculiarity of absentee proceedings is that they are not adversarial proceedings in this very own sense. That is why, in order to ensure equality of the parties in court proceedings, the defendant is granted the right to appeal against the decision in absentia to the court that adopted it, within seven days from the date when a copy of the decision was delivered to him/ her (Part 1 of Article 237 of the Civil Procedure Code of the Russian Federation). This is done when there are special grounds (failure to appear is connected with valid reasons about which the defendant could not timely notify the court; the defendant refers to the circumstances and presents evidence that may affect the content of the court decision - Para. 3 Part 1 of Art. 238, and Art. 242 of the RF CPC). The result of the meeting the defendant's application to cancel the absentee decision is the resumed consideration of the case on the merits, i.e., the 
fulfilment of ordinary, "extended" procedure of court proceedings.

Thus, the proceedings in absentia are a judicial procedure, which has its subject and task of ensuring the right to judicial protection, to the full use of the civilized procedural form in the court proceedings. Neither simplification nor acceleration of the process is its goal. By the way, let us compare: the mere failure of the defendant to appear without a valid reason, when he/she has not ask for the consideration of the case in his/her absence, is not an absolute, objective reason for the absentee proceedings. In such circumstances a case can be considered in accordance with the general rules of court proceedings (Part 4 of Article 167 of the Civil Procedure Code of the Russian Federation). Moreover, in the absence of both parties, proceedings in absentia are not possible, though the case can be considered in their absence if there are grounds for this established by law (Article 167 of the Civil Procedure Code of $\mathrm{RF}$ ). Absentee proceedings obtain procedural qualification in the presence of the will of the plaintiff, and this is right given the concept of this procedure. I believe that de lege feren$d a$ this aspect can be strengthened, as the law should directly stipulate that the procedure of absentee proceedings (if there are grounds for it established by law) is possible: a) at the initiative of the plaintiff, expressed in the statement of claim or in the petition about that; b) at the initiative of the court with the consent of the plaintiff. It is consistent with a modern tendency of strengthening of private law principles in civilistic process and at the same time corresponds to the traditional postulate of the Russian process about subjective awareness of the need in the process (and in the certain procedure of the case consideration - Author's note) as the only basis for initiation of the process of judicial defence and for the process itself.

The procedure of trial in absentia, along with other judicial procedural practices, attests to the complication of the procedural form. In addition to that, differentiation of the form of the process by the procedural criterion is not an end in itself, but an objective need aimed at increasing the efficiency of the judicial protection by means of private legal methods - through maximizing the significance of the procedural expression of the will of the parties concerned while choosing procedural means and methods of protection.

\section{Minor cases procedure}

Minor cases procedure is close to conducting trials on claims at the magistrate court (cf.: Para. 2-5 Part 1 of Article 23 of the Civil Procedure Code of the Russian Federation). The current legislation does not provide for any procedural specifics; the jurisdiction of the magistrate court is established imperatively and there is only one peculiarity related to the issuance of a court decision: "The magistrate court has the right not to draw up a reasoned court decision on a case considered" (Part 3, Article 199 of the Civil Procedure Code of the Russian Federation), unless an application for a reasoned court decision has been received from the persons involved in the case (Part 4, Article 199 of the Civil Procedure Code of the Russian Federation). Since it is obvious that literally following this rule may encumber the exercise of the right to appeal, in 2013 the Presidium of the Supreme Court of the Russian Federation made a judgment according to which "if persons involved in the case did not apply to the magistrate court in accordance with the procedure set forth in Part 4 of Article 199 of the Civil Procedure Code of the Russian Federation, with an application to draw up a reasoned court decision, but later they filed an appeal or production in court against this decision, in that case the magistrate court should draw up a reasoned decision". ${ }^{16}$ However, in 2017, the Plenum of the RF Supreme Court formulated a different position. Giving explanations as to the application by arbitration courts of the Part 2, Article 229 of the Arbitration Procedure Code of the Russian Federation (as amended in 2016, so that now it enables delivering a judgemnet in a case considered in simplified proceedings only following the application of a person involved in the case), the Plenum stated that "an

\footnotetext{
${ }^{16}$ Review of judicial practice of the Supreme Court of the Russian Federation for the second quarter of 2013, approved by the Presidium of the Supreme Court of the Russian Federation on November 20, 2013. In Bulletin of the Supreme Court of the Russian Federation, 2014, 1.
} 
appeal shall be lodged against a decision taken by way of signature of the operative part", but "a court of general jurisdiction or an arbitration court may produce a reasoned decision on its own initiative". ${ }^{17}$ As is well known, the situation in the simplified proceedings changed with the adoption The Federal Law of the Russian Federation No. 451-FZ on November 28,2018 , and its introduction into force. The grounds for a reasoned decision by a court (of general jurisdiction or an arbitration court) have been unified; these grounds now include both an application by a person involved in the case and an appeal.

Assessing the desire of the Supreme Court of the Russian Federation to improve the situation related to the enforcement of the right to appeal, it should be emphasized that the problem cannot be reduced to it. So, there is confusion about the properties of legal force (in particular, issue preclusion), the objective limits of legal force of a court decision issued without a reasoned part. These apparent aspects were noticed and, naturally, were mostly criticized as undermining the essence of a court decision as an act of justice. It is difficult to disagree with this, and I do not want to contradict the most of the arguments put forward. But I would have highlighted something else. The discussions follow several written rules. Meanwhile, we are talking here about a completely different phenomenon, which has the right to exist. The whole problem is in the incorrect approach of the legislators to the criteria of differentiation of court procedures. In this case, they as if grope their way. Problems, we think, arise because the legislators have imperatively linked the subject insignificance with the absence of the reasoned part of the court decision, while the search for justice (=fairness) by default cannot depend on the price of the amount claimed. The situation would be fundamentally different if the possibility of making a court decision without a reasoned part was made dependent upon the

\footnotetext{
17 On Some Issues of Application of the Provisions of the Civil Procedure Code of the Russian Federation and the Arbitration Procedure Code of the Russian Federation. Resolution of Plenum of the Supreme Court of the Russian Federation of April 18, 2017, No. 10. In Bulletin of the Supreme Court of the Russian Federation, 2017, 6 .
}

positive expression of the will of the parties their outwardly expressed consent to making such a decision. This is all the more justified in case of possible de facto competition between the rules of Part 3 of Article 199, Part 2 of Article 232.2, Part 2 of Article 232.2. 2, Part 2 of Article 232.4 of the Civil Procedure Code of the Russian Federation. They state that with the consent of the parties, the cases to be considered in the magistrate courts under Para. 2-5 of Part 1, Art. 23 of the Civil Procedure Code of the Russian Federation, may be considered during simplified proceedings. As a result, there is some "overlapping" of procedures. The substantive (material-legal) criterion of insignificance imposed by the legislator is undermined from the inside by the procedural properties of the simplified proceedings. It seems more rational to follow methodologically unified procedural criteria in creating the legislative concept of judicial procedures.

\section{Conclusion}

The pivotal novelties of the Russian civilistic process in 2018-2019, which go under the banner of the unification of the process, mark, as I see it, a new stage in the development of procedurality of the process and update the private legal methodology of judicial protection. I take this as a crucially important and the most momentous event after the adoption of the Civil Procedure Code of the Russian Federation and the Arbitration Procedure Code of the Russian Federation in 2002. Definitely, there is something else to work on in the given area: the contradictions of the ontological character in the proposed legal regulation, the absence of a single and substantiated criterion of differentiation of both judicial procedures and civilistic process as a whole are the tasks to be solved by legislators. The difficulties in this case are understandable: the Russian process of modern times developed mainly as an institutional process. The procedural nature of the Russian process, which was laid down in the codes of the early $20^{\text {th }}$ century, now acquires conceptual significance, which calls for different methods of solving current legislative problems. The procedures studied here are like a "litmus paper" for process methods, allowing 
us to comprehend the general tendency of the further way towards reforming the civilistic process, whose prospect is seen in the consis- tent strengthening of the private law basis as the main means of objectification of justice in the procedural matter of judicial protection.

\section{References}

Gromoshina, N.A. (2010). Differentsiatsia, unifikatsiia i uproshchenie v grazhdanskom sudoproizvodstve [Differentiation, unification and simplification in civil proceedings]. Moscow, $264 \mathrm{p}$.

Iarkov, V.V. (2012). Iuridicheskie fakty v tsivilisticheskom protsesse [Legal facts in civilistic process]. Moscow, Infotropik Media, $608 \mathrm{p}$.

Kudriavtseva, E.V. (2008). Grazhdanskoe sudoproizvodstvo Anglii [Civil proceedings in England]. Moscow, $320 \mathrm{p}$.

Kudryavtseva, E.V. (2010). Prikaznoe proizvodstvo. Grazhdanskii protsess, ucheblik [Writ proceedings. Civil proceedings, textbook (edited by M.K. Treushnikov)], 412-423. Moscow, Statut.

Kudryavtseva, E.V. (2010). Zaochnoe proizvodstvo i zaochnoe reshenie. Grazhdanskii protsess, uchebnik [Proceedings in absentia and judgement in default. Civil Proceedings, textbook (edited by M.K. Treushnikov)], 424-434. Moscow, Statut.

Malyshkin, A.V. (2017). Kategorii del, podlezhashchikh rassmotreniiu v poriadke uproshchennogo proizvodstva: integrirovanie prikaznoi i obshcheiskovoi iurisdiktsii [Categories of cases to be considered under the simplified procedure: integration of writ proceedings and general jurisdiction]. In Vestnik grazhdanskogo protsessa [Bulletin of Civil Procedure], (4), 234-246.

Nefed'ev, E.A. (2005). Uchebnik russkogo grazhdanskogo sudoproizvodstva [Textbook of Russian civil proceedings]. Krasnodar, $480 \mathrm{p}$.

Nefed'ev, E.A. (2005). Uchenie ob iske. Izbrannye trudy [Doctrine about the lawsuit. Selected works]. Krasnodar, $400 \mathrm{p}$.

Reshetnikova, I.V. (2013). Uproshchennoe proizvodstvo [Simplified proceedings]. In Kontseptual'nyi podkhod, zakon [Conceptual Approach, Law], (4), 93-98.

Reshetnikova, I.V. (2019). Razmyshliaia o sudoproizvodstve: Izbrannoe [Reflecting on the judicial proceedings: Selected works]. Moscow, Statut, $510 \mathrm{p}$.

Reshetnyak, V.I., Chernykh I.I. (1997). Zaochnoe proizvodstvo i sudebnyi prokaz v grazhdanskom protsesse [Proceedings in absentia and court writ in civil proceedings]. Moscow, $80 \mathrm{p}$.

Sakhnova, T.V. (2004). Novye GPK i APK RF: edinstvo protsessa? [New Civil Procedure Code and Arbitration Procedure Code of the RF: unity of the process?]. In Materialy Vserossiiskoi nauchno-prakticheskoi konferentsii “APK $i$ GPK 2002: sravnitel'nyi analiz i aktual'nye problem pravoprimenennia [Materials of the All-Russian Scientific and Practical Conference "APC and CPC 2002: Comparative Analysis and Actual Problems of Law Enforcement”'], 25-35. Moscow, April 2-3, 2003, Russian Academy of Justice.

Sakhnova, T.V. (2008). Zakonnaia sila kak atribut pravosudiia [Legitimacy as an attribute of justice]. In Materialy mezhdunarodnoi nauchno-prakticheskoi konferentsii, posviashchennoi pamiati professor, doktora iur. nauk, Zasluzhennogo rabotnika Vysshei Shkoly RF N.A. Chechinoi "Tendentsii razvitiia grazhdanskogo protsessual'nogo prava" [Materials of the International Scientific and Practical Conference dedicated to the memory of Professor, Doctor of Law, Honoured Worker of the Higher School of the Russian Federation N.A. Chechina "Trends in Development of Russian Civil Procedural Law"], 98-117. St. Petersburg, 9-10 February 2007.

Sakhnova, T.V. (2009). Protsedury v tsivilisticheskom protsesse (nota bene $k$ budushchemu [Procedures in civilistic process (nota bene for the future)], 71, 25-40. Teise.

Sakhnova, T.V. (2011). O printsipakh tsivilisticheskogo protsessa (v kontekste "evropeizatsii" protsessual'nogo prava [On principles of civilistic process (in the context of "Europeanization" of procedural law]. In Rossiiskii ezhegodnik grazhdanskogo i arbitrazhnogo protsessa [Russian yearbook of civil and arbitration process], (7-8), 44-53. 
Sakhnova, T.V. (2014). Kurs grazhdanskogo protsessa [Course on civil procedure, $2^{\text {nd }}$ edition]. Moscow, Statut, 784 p.

Sakhnova, T.V. (2015). O kontsepte edinogo Grazhdanskogo protsessual'nogo kodeksa Rossii (zametki po povodu) [On the concept of a unified code of civil procedure of Russia (notes on the subject)]. In Vestnik grazhdanskogo protsessa [Bulletin of Civil Procedure], (1), 9-27.

Sivak, N.V. (2011). Uproshchennoe proizvodstvo v arbitrazhnom protsesse [Simplified proceedings in arbitration court]. Moscow, Prospekt, $136 \mathrm{p}$.

Terekhova, L.A. (2018). Osobennosti obzhalovaniia sudebnykh prikazov i reshenii po delam uproshchennogo proizvodstvsa [Features of appeal of court writs and decisions in simplified proceedings]. In Arbitrazhnyi i grazhdsnskii protsess [Arbitration and civil proceedings], (11), 21-25.

Tumanov, D.A. (2016). Eshche raz o tom, iavliaetsia li sudebnyi prikaz aktom pravosudiia, ili Razmyshleniia o sushchnosti pravosudiia [Once again on whether a court writ is an act of justice, or Reflections on the essence of justice]. In Zakony Rossii: opyt, analiz, praktika [Laws of Russia: Experience, Analysis, Practice], (9), 13-20.

Vas'kovskii, E.V. (2003). Uchebnik grazhdanskogo protsessa [Textbook of Civil Proces]. Krasnodar, $528 \mathrm{p}$.

\title{
Развитие упрощенных процедур в цивилистическом процессе России в контексте законодательных реформ
}

\author{
T.В. Сахнова \\ Сибирский федеральный университет \\ Российская Федераичи, Красноярск
}

\begin{abstract}
Аннотация. Статья посвящена проблемам, связанным с унификацией ряда судебных - процессуальных и непроцессуальных - процедур в современном цивилистическом процессе России, под онтологическим углом зрения и с учетом законодательных новелл 2018-2019 гг. Унификация и дифференциация судебных процедур - двуединая тенденция цивилистического процесса, обусловленная глобализацией процессуального права в XXI в. Вместе с тем общая закономерность реализуема различными методами в зависимости от типа процесса и его национального концепта. Судебные процедуры, имеющие структурную специфику по отношению к общей («развернутой»), не ведут к упрощению, а, наоборот, свидетельствуют об усложнении цивилистического процесса. В работе обоснован тезис, что повышение коэффициента прикладной эффективности такого процесса может быть достигнуто только балансом частноправовых и публично-правовых начал в судебных процедурах. Выводы относительно сущности судебных процедур и методологии их воплощения в процессуальном законе могут быть использованы в законотворческой и правоприменительной деятельности.
\end{abstract}

Ключевые слова: цивилистический процесс, судебные процедуры, упрощенное производство, приказное производство, заочное производство, производство по малозначительным требованиям, справедливость.

Научная специальность: 12.00.15 - гражданский процесс, арбитражный процесс. 